Trinity University

Digital Commons@ Trinity

Library Faculty Research

Coates Library

2017

\title{
The E-Resources Playbook: A Guide for Establishing Routine Assessment of E-Resources
}

Lanette Garza

Trinity University, lgarza1@trinity.edu

Follow this and additional works at: https://digitalcommons.trinity.edu/lib_faculty

Part of the Library and Information Science Commons

\section{Repository Citation}

Garza, L. (2017). The e-resources playbook: A guide for establishing routine assessment of e-resources. Technical Services Quarterly, 343, 243-256. doi: 10.1080/07317131.2017.1321373

This Post-Print is brought to you for free and open access by the Coates Library at Digital Commons @ Trinity. It has been accepted for inclusion in Library Faculty Research by an authorized administrator of Digital Commons @ Trinity. For more information, please contact jcostanz@trinity.edu. 


\title{
The E-Resources Playbook: A Guide for Establishing Routine Assessment of E-Resources
}

\author{
Lanette Garza
}

\begin{abstract}
Assessment of ongoing or potential electronic purchases has always been a challenging and time consuming process for librarians. In most cases, the organization, maintenance, sharing, and use of electronic resources data can be overwhelming. Diligent planning, monitoring, and assessment of e-resources is more important than ever. This article lays out the step-by-step process of creating an e-resources assessment playbook. This playbook will essentially be a book of strategies that will help orchestrate and illustrate steps and techniques for carrying out particular e-resources reports.
\end{abstract}

Keywords: Electronic Resources, Assessment, Reports Schedule, Database Statistics, Trials, Dashboards, Klipfolio

Author's Note: Lanette Garza, Resource Management \& Assessment Librarian at the Coates Library at Trinity University, San Antonio, TX 78212. Lgarza1 @ trinity.edu

Received: September 30, 2016

Accepted: December 16, 2016 


\section{The E-Resources Playbook: A Guide for Establishing Routine Assessment of E-Resources}

For most libraries, electronic resources represent the primary expenditure of materials and collections budgets. According to the Association of College and Research Libraries (ACRL), libraries spend $68.7 \%$ of their total materials budget on electronic resource purchases and subscriptions (Petrowski, 2015). Considering the growing demand for and cost of eresources, it has become even more important that we understand their use and their value to our patron communities. At the same time, assessment of ongoing or potential purchases has always been a challenging and time-consuming process for librarians. In some cases, we may have a wealth of available information intended to help us to make decisions, but the organization, maintenance, sharing, and use of that data can be overwhelming. Diligent planning, monitoring, and assessment of e-resources is more important than ever, yet this workflow of tasks and documents remains challenging for many.

An e-resources "playbook" can help us to strategize and document the various methods and tools useful for the evaluation and assessment of our e-resources collections. This assessment playbook has the potential to reflect a plan, an approach, and a strategy to create a predictable and clear assessment routine. It will essentially be a book of strategies to help orchestrate and illustrate steps and techniques for carrying out particular e-resources assessment reports. Like "playbooks" used in various sports as a means of formulating and executing "plays" that will help a team to succeed, a playbook for e-resources assessment provides a viable model for a more holistic, regularized, and supportive workflow. The most basic e-resources playbook will consist of the following plays each containing two elements formation and execution. 

1) E-reports schedule
2) Annual reports
3) Discovery reports
4) Trials
5) Use of resources report

The playbook provides a strong foundation for assessment work whether completed by an individual working alone or one working as part of a team. It can foster coordination, communication, and collaboration. Set the assessment "plays" within the playbook, create the foundation for a strong routine, and then let the decision-making emerge.

\section{Literature Review}

There are several articles on e-resource assessment and how assessment should be approached, but most literature focuses explicitly on the actual assessment rather than the assessment workflow of various e-resource tasks. Research presented in Techniques for Electronic Resource Management (TERMS), a project started by Emery and Stone, (2014) helped to establish a framework for understanding best practices in the e-resources world. The TERMS project is an attempt to fill the workflow management gap for e-resources. In particular, step four in the TERMS project highlights ongoing evaluation and access. Emery and Stone (2014) provide the following:

In order for the evaluation to be most beneficial to your institution, the librarians at any given institution must first agree on which data points they would like to use to evaluate their electronic usage and then set consistent methods of collecting and reporting these figures from one year to the next (p. 58). 
This sentiment reinforces a similar call by the authors of a 2012 article, “...to move beyond the familiar crisis/response model of assessment to something that is more regularized and supportive of the health of our collections" (Carroll, Major, O'Neal, \& Tofanelli, 2012). Nagra ( (2009) also makes a strong case for establishing a model for evaluation of use of electronic resources and services. She argues that libraries need a clear, solid and reliable plan to evaluate electronic resources and services.

Challenges to collecting and analyzing e-resource data have long been centered on issues with data collection (Fons \& Jewell, 2007). Fortunately, in 2001 the International Coalition of Library Consortia (ICOLC) developed the first guidelines for reporting electronic usage statistics. Project COUNTER (COUNTER Codes of Practice, 2016) went a step further and specified how vendors should measure and report statistics. COUNTER is now in its fourth release and includes data elements, protocols, standard reports in standard formats, and an auditing requirement (Shepherd, 2006). However, in 2007, Fons and Jewell explained that COUNTER would improve libraries' ability to work with usage statistics but without "other" improvements these tasks would likely continue to be overwhelming. The lingering difficulty lies in the establishment of methods for gathering the many reports and establishing a routinized schedule for the many assessment measures.

This difficulty is reiterated by Covey (2002) who discusses library practices and concerns regarding usage and usability assessment. Her survey indicates the significant challenges to assessing use of digital collections. In particular, she identified the following challenges: 1) Developing skills to gather, analyze, interpret, present, and use data; 2) Developing comprehensive assessment plans; 3) Organizing assessment as a core activity; and 4) Compiling and managing assessment data. Her work clearly confirms that planning assessment 
from conception through follow-up can be a difficult task. Much like Covey's argument, Peters (2002) wrote, "Two things are needful to make usage statistics of e-resources truly useful: broadly adopted standards and continual practices" (p. 12).

Fry (2013), however, attempts to deal with these challenges by presenting a hybrid workflow model for electronic usage assessment. Her hybrid model was created specifically to combat the difficulty of collecting, managing, and assessing the flood of usage data. Fry's proposal takes advantage of current standards, available software, and local institutional knowledge. She argues that since the development of COUNTER, more and more vendors have adopted strong and consistent standards, but it is the second part of the process that is more difficult. "Libraries need a solid theoretical framework to approach the project of collecting and reporting e-resource usage statistics...this is where practice is key” (Fry, 2013, p. 27). Fry's hybrid model is a well-defined and suitable workflow for usage assessment. The e-resources playbook furthers the idea of creating a culture of continual practice that moves beyond the workflow in order to foster meaningful discussions and make valuable decisions.

\section{Institutional Profile}

Trinity University is a small liberal arts university located in San Antonio, Texas. The university serves 2,353 undergraduate and graduate students within 47 different academic majors. The Coates Library at Trinity University is deeply committed to serving the institution's pursuit of excellence and innovation in teaching, learning, research, service, leadership, and personal development. In addition to serving students, the library supports the instruction and research of over 247 faculty members. In the 2014-2015 academic year, there were 69,049 print circulation transactions and 408,181 online searches through the Coates Library. The library has 
864,328 books and bound periodicals, along with 95,000 journals accessible via e-subscriptions and databases. The library has a materials-and-acquisitions budget of $\$ 1.7$ million.

After a recent reorganization of the library's Technical Services Department, the Head of Resource Management and Discovery is responsible for the management of budgets and acquisitions. Reporting to that position is the Resource Management and Assessment Librarian, who is responsible for the assessment of all e-resources within the library. Before this reorganization, data-collection methods and the sharing of information across units was inconsistent. A number of checklists were in place to assist with routine tasks, such as acquiring and cancelling database subscriptions, setting up trials, and so on. These checklists helped to record staff activities but did not help to improve workflow efficiency. Neither previous methods for collecting and assessing data nor the library's management system (Sierra) were adequate. Using Innovative Interfaces’ Electronic Resource Management (ERM) module, along with homegrown Excel templates for data collection and Klipfolio software for presentation purposes, staff developed the playbook approach as an effect to improve collection, organization, assessment, and presentation of e-resources assessment.

\section{The Playbook}

\section{E-Reports Schedule}

Formation. In order to have a high-functioning playbook, creating a schedule for all major e-resources reports is the first crucial play. The schedule essentially provides the eresources overview for the library, sets the goals and vision for the year, and provides a timeline for completing and reviewing reports. Establishing such a schedule helps with prioritizing responsibilities as well as creating balance between assessment activities and the other various 
tasks librarians and staff are responsible for accomplishing. The creation of the e-reports schedule will result in a more strategic approach to future library planning and purchasing.

Execution. Using Microsoft Excel for ease and functionality, there are four steps involved in the creation of the schedule. The first step is to determine the purpose of e-reports collection. What is the purpose of gathering these statistics? How might each report be useful and how might the reports be valuable when collected and compared? Think about the library's goals and let them guide the completion of the process.

The second step is to list all statistics and reports to be collected. The list should include basic reports, such as statistics on subscription databases, purchased databases, renewals, ebooks, pay per view (PPV), institutional repository, and journal subscriptions.

The third step is to determine dates. Decide on realistic due dates for each report. Consider how long it will take to compile and complete the report from beginning to end and allow for more time, if possible, to complete these reports; it is far better to finish a report earlier than to consistently miss any deadlines. Document the due date(s), the collection date(s), and finally the completion date. The completion date will help when revising the schedule for the subsequent year.

The final step is to reevaluate and note any lessons learned. Reevaluate the entire schedule at the end of the year. The schedule, at times, might not be all-inclusive. There are several adhoc reports that might come into play that will need to be considered. Adjustments to dates will likely need to be made frequently, especially during the first year using this schedule and more and more reports will be added to the schedule each year. Excel makes it easy enough to easily adjust and revise dates. With crafting and revision, over time the e-reports schedule should serve as the "go to" play (see Figure 1). 


\begin{tabular}{|c|c|c|c|c|c|c|}
\hline \multicolumn{7}{|c|}{ Reports 2017} \\
\hline Deadline & Report/Data & Description & Collection & Collection Notes & Report Recipients & $\begin{array}{c}\text { Completion } \\
\text { Date }\end{array}$ \\
\hline January & ContentDM Report & $\begin{array}{l}\text { Report to include Page Views and month to month } \\
\% \text { increase/decrease }\end{array}$ & January & Pulling from the Digital Commons Platform & $\begin{array}{l}\text { Stats to be emailed to the Special } \\
\text { Collections Librarian }\end{array}$ & \\
\hline January & $\begin{array}{l}\text { Cambridge Journals Online } \\
\text { Package }\end{array}$ & $\begin{array}{l}\text { Review Cambridge E-Journals by subscribed vs. } \\
\text { unsubscribed }\end{array}$ & January & $\begin{array}{l}\text { Pull data from administration site and Harrassowitz E-Stats } \\
\text { report }\end{array}$ & $\begin{array}{l}\text { Stats to be emailed to the Head of } \\
\text { Discovery Services: }\end{array}$ & \\
\hline January & $\begin{array}{l}\text { Contact Vendors to Receive } \\
\text { Licenses }\end{array}$ & License Project & $\begin{array}{l}\text { November- } \\
\text { January }\end{array}$ & Contact Vendors to Receive Licenses & & \\
\hline \multicolumn{7}{|c|}{ February - March (Trial Season: Set-up Trials \& Gather Feedback } \\
\hline \multicolumn{7}{|c|}{ February - March (Review Potential Resources in SCELC and Provide our Review) } \\
\hline February & EDS Search Terms Report & Summary report for the end of the Fall semester & February & Pull from google analytics on the EDS & $\begin{array}{l}\text { Stats to be reviewed by Head of } \\
\text { Resource Management and Discover } \\
\text { and the Liaisons }\end{array}$ & \\
\hline February & Trials Master List Update & Update Master List with Fall trials & February & $\begin{array}{l}\text { Add Fall trials to the Master list (update in excel and upload } \\
\text { into google drive docs as well) }\end{array}$ & $\begin{array}{l}\text { List can be viewed in at any time in } \\
\text { the Trials folder }\end{array}$ & \\
\hline$\underline{\text { February }}$ & All Resource Records & $\begin{array}{l}\text { Pull a list of all Resource Records currently in Sierra. This } \\
\text { will be used a quick reference for identifying databases we } \\
\text { have and information regarding those databases }\end{array}$ & January & $\begin{array}{l}\text { Pull list from Sierra (list should already be a saved query } \\
\text { called, All Resource Records) }\end{array}$ & Reported located in: & \\
\hline March & E-Stats Report Update & $\begin{array}{l}\text { Once the E-Stats Q4 Report is received, I will need to } \\
\text { combine the new year/data to the existing E-Stats Master } \\
\text { Report }\end{array}$ & $\begin{array}{l}\text { February- } \\
\text { March }\end{array}$ & $\begin{array}{l}\text { Gather stats from E-Stats Report; Remember to provide } \\
\text { subject links that provide all of the aggregator access despite } \\
\text { lacking direct access }\end{array}$ & $\begin{array}{l}\text { Stats to be reviewed by Head of } \\
\text { Discovery Services and E-Content } \\
\text { Librarian }\end{array}$ & \\
\hline March & $\begin{array}{l}\text { JSTOR Archive, CSP \& } \\
\text { Chicago }\end{array}$ & Review JSTOR packages & March & Pull from JSTOR administration site & $\begin{array}{l}\text { Stats to be emailed to the Head of } \\
\text { Discovery Services }\end{array}$ & \\
\hline March & Wiley & Review Wiley package & March & Pull from Wiley administration site & $\begin{array}{l}\text { Stats to be emailed to the Head of } \\
\text { Discovery Services \& discussed with } \\
\text { all Liaisons }\end{array}$ & \\
\hline March & Springer & Review Springer package & March & Pull from Springer administration site & $\begin{array}{l}\text { Stats to be emailed to the Head of } \\
\text { Discovery Services }\end{array}$ & \\
\hline
\end{tabular}

Figure 1. E-Reports Schedule.

\section{Annual and Reoccurring Reports}

\section{Database Statistics and Renewal Reports}

Formation. Database statistics reports tend to focus on measuring the number of times a database is searched and the number of articles downloaded as full-text from the database. This type of usage data offers compelling evidence on whether a database should be supported by purchase or subscription. The goal for this report is to collect, compile, and review. The statistics should be collected at the end of the each month for the previous month. At the end of the year, the data should be analyzed and presented in a summary report. Then a decision should be made as to which databases will undergo an even more thorough review and discussion among the librarians. For example, the first year of review might cover only those databases that are fully purchased. Numbers can be reviewed so that more marketing can be done. The following year a review of the top 20 databases with low use should be reviewed in order to determine if the resource is worth keeping. 
Execution. Database statistics can be efficiently collected in Excel templates. All data compiled on database usage should be based on COUNTER reports (COUNTER Codes of Practice, 2016). COUNTER 4 is the newest standard in usage reporting for online journals, databases, books, and multimedia content. COUNTER 4 was released to institutions in February 2014, but some made the transition later than others. COUNTER 4 included changes to existing usage reports and also introduced new usage reports, such as Gold Access report, Access Denied report, Year-of-Publication report, Select Time Range report, and more. In the case where a database vendor does not comply with COUNTER data standards, a decision must be made to either exclude it from the spreadsheet or to make a note indicating the measure/standard that will be used for that database instead. Including the cost per use (CPU) of each database is also of central importance. CPU informs the renewal and/or cancellation process as it helps to document the value of the resource.

The Database Statistics Report is organized by database subscriptions, purchases, and streaming media databases. The Excel spreadsheet is first sorted by vendors (e.g. ASP, Ebscohost, Gale, Oxford, and so on) and then by consortium (e.g. Texshare vs. non-Texshare). Conditional formatting is used to show visually whether usage has increased or decreased from the previous year by vendor group.

Currently, the database report includes usage based on full-text downloads and searches only. Decisions were made throughout the years with regard to what usage would be tracked. A group decision was to exclude the number of "sessions" per database. The data currently represents the number of full-text articles downloaded from the Journal Report 1 (JR1) and information about searches that have been conducted in the Databases Report 1 (DR1). The report includes the vendor, database name, liaison, YTD total, percent change, and fiscal year 
totals dating back to 2009. The data is also grouped by consortia, if applicable. This helps with further evaluation of consortium memberships (see Figure 2).

\begin{tabular}{|c|c|c|c|c|c|c|c|c|c|c|c|c|c|c|c|c|c|c|c|}
\hline CONSOR & VENDOR & DATABASE & Liaison & Jun:-16 & Jul-16 & Aug. 16 & Sep. 16 & Ott-16 & Nov-16 & Dec.16 & Jan-17 & Feb-17 & Mar 17 & Apra.17 & May-17 & FY 16/17 & $\begin{array}{l}16 / 17 \\
\text { Price }\end{array}$ & CPU & YChang \\
\hline EBSCOhost TOTAL & & & & 0 & 0 & 0 & 0 & 0 & 0 & 0 & 0 & 0 & 0 & 0 & 0 & & 0 & & $\sqrt{8}-100,0$ \\
\hline GALE Group TOTAL & & & & 0 & 0 & 0 & 0 & 0 & 0 & 0 & 0 & 0 & 0 & 0 & 0 & & 0 & & $\sqrt{8}-100,0$ \\
\hline OCLCTOTAL & & & & 0 & 0 & 0 & 0 & 0 & 0 & 0 & 0 & 0 & 0 & 0 & 0 & & 0 & & \\
\hline TEXSHARE TOTAL & & & & 0 & 0 & 0 & 0 & 0 & 0 & 0 & 0 & 0 & 0 & 0 & 0 & & 0 & & $\sqrt{8}-100,0$ \\
\hline ASP TOTAL & & & & 0 & 0 & 0 & 0 & 0 & 0 & 0 & 0 & 0 & 0 & 0 & 0 & & 0 & & $\sqrt{8} \cdot 100,0$ \\
\hline EBSCOhost TOTAL & & & & 0 & 0 & 0 & 0 & 0 & 0 & 0 & 0 & 0 & 0 & 0 & 0 & & 0 & & $\sqrt{8} \cdot 100,0$ \\
\hline GALETOTAL & & & & 0 & 0 & 0 & 0 & 0 & 0 & 0 & 0 & 0 & 0 & 0 & 0 & & 0 & & $8-100,0$ \\
\hline NewsBankTOTAL & & & & 0 & 0 & 0 & 0 & 0 & 0 & 0 & 0 & 0 & 0 & 0 & 0 & & 0 & & $\sqrt{8} \cdot 100,0$ \\
\hline Oxford TOTAL & & & & 0 & 0 & 0 & 0 & 0 & 0 & 0 & 0 & 0 & 0 & 0 & 0 & & 0 & & $\sqrt{8}-100,0$ \\
\hline ProQuest TOTAL & & & & 0 & 0 & 0 & 0 & 0 & 0 & 0 & 0 & 0 & 0 & 0 & 0 & & 0 & & $\sqrt{8}-100,0$ \\
\hline MISC, TOTAL & & & & 0 & 0 & 0 & 0 & 0 & 0 & 0 & 0 & 0 & 0 & 0 & 0 & & 0 & & $\sqrt{8}-100,0$ \\
\hline \multicolumn{2}{|c|}{ NON-TEXSHAREETOTAL } & & & 0 & 0 & 0 & 0 & 0 & 0 & 0 & 0 & 0 & 0 & 0 & 0 & & 0 & & $\sqrt{8}-100,0$ \\
\hline \multicolumn{2}{|c|}{ FULL-FEXT GRAND TOTAL } & & & 0 & 0 & 0 & 0 & 0 & 0 & 0 & 0 & 0 & 0 & 0 & 0 & 0 & 0 & & $-100,0$ \\
\hline
\end{tabular}

Figure 2. Subscription Database Statistics Spreadsheet.

Another addition to the database statistics report is a tab for purchased databases, which are those databases that have been fully purchased and require only an annual maintenance or hosting fee. Despite the fact that these resources have already been purchased, usage data can help the institution be more strategic about marketing their value. The final tab of the spreadsheet contains usage data on streaming-media resources. Depending on the size of the collection it might be beneficial to review the use of these resources closely. Streaming-media databases quite often do not comply with COUNTER reporting. Therefore, these databases will need to be annotated to describe and note how the information was gathered and what the data represents.

The Databases Statistics Report is a great way for liaisons to evaluate their resources throughout the year, and having the data available in this annual report makes gathering renewal statistics much more efficient. Out of the annual database statistics report, the renewal database statistics were born in order to create an individualized renewal report for liaisons. This report provides a personalized and individualized snapshot of the use of a particular database. When vendors send notifications indicating that a particular e-resource is up for renewal or about to be 
terminated within the next 30 days, the usage on that database needs to be pulled and compiled. In addition to the usage, cost analysis over the past 3 to 5 years should also be reported.. A visual representation of the data should also be included. The spreadsheet is then sent to the liaison and a decision is made whether to cancel or renew and the decision is documented. Providing these statistics to liaisons informs them and gives them greater authority when decisions must be made regarding particular resources (see Figure 3).

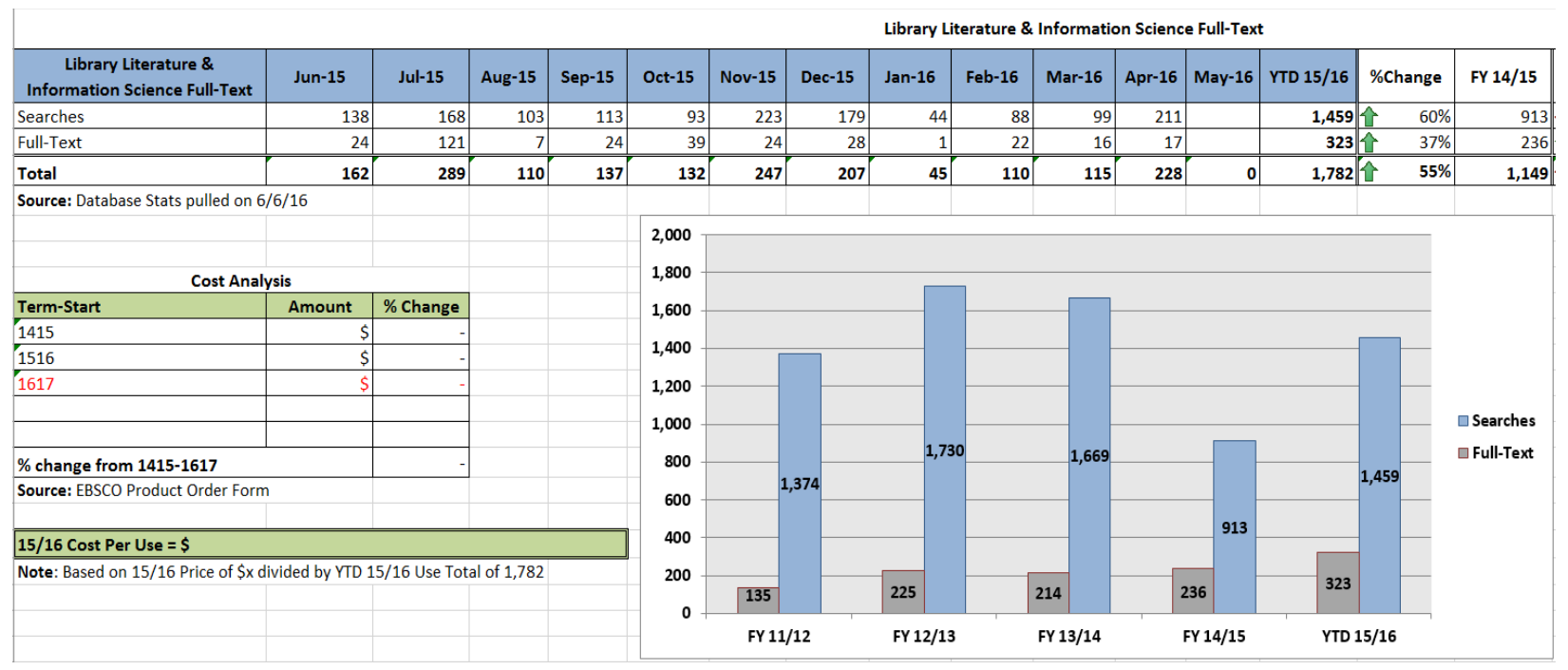

Figure 3. Renewal Database Statistics Report.

\section{E-Book Report}

Formation. The e-book report looks at both total use of e-books as well as individual package use. In the planning phase of this report, consider the complexity of e-book packages. Many e-book packages, in their current form, are confusing to access and come in a variety of different packages. Thus, assessment of e-books usage can be troublesome. Many e-book vendors still require users to sign onto multiple platforms before getting the book. Strict lending models with terms that translate into different lending models and create digital restrictions, otherwise known as walled gardens, which are mostly set by publishers. Some publishers offer 
different checkouts (2 days, short-term loans, triggers) and even require additional software that must be downloaded and installed.

The plan should involve a decision as to what e-book platforms will be included in the report and then determine what standard for usage will be included. Decide on what the e-content equivalent to a "print checkout" will be used in the report. An e-book checkout can be gathered from COUNTER reports, using the BR1 or BR2, which gather the number of successful title requests and the number of successful section requests by month and book title. When a student checks out a print book, librarians do not always know if they are reading the entire book or merely a chapter or section of it. Because e-books are often downloaded by a particular chapter or section, BR2 is often the standard for assessing e-book use.

Execution. Much like the database statistics spreadsheet, the e-book report is also completed in Excel, although, statistics are collected for each platform only on an annual basis. The report is generated in the summer months and provides the total use, by platform, for that particular fiscal year. Additionally, this report provides in-depth data for each platform, presenting title-by-title use. The COUNTER data is pulled from each vendor's administration site and compiled. Cost is also collected and documented in the report to provide a general analysis of Cost Per Use (CPU) (see Figure 4).

\begin{tabular}{|c|c|c|c|c|c|c|c|c|c|}
\hline \multicolumn{10}{|c|}{ Trinity University - Coates Library - Ebooks Summary Report } \\
\hline Vendor & Ebook Collection & \begin{tabular}{|c} 
Source \\
Type
\end{tabular} & FY $12 / 13$ & FY $13 / 14$ & FY $14 / 15$ & FY $15 / 16$ & \begin{tabular}{c|}
$\%$ \\
Change
\end{tabular} & Cost FY15/16 & $\begin{array}{c}\text { Annual } \\
\text { Fee }\end{array}$ \\
\hline ProQuest & Ebrary & BR2 & & & & & & & \\
\hline EBSCO & eBook Academic Collection & BR2 & & & & & & & \\
\hline Gale & GVRL & BR2 & & & & & & & \\
\hline Oxford & *Oxford Handbooks Online & BR2 & & & & & & & \\
\hline Cambridge & Cambridge Histories Online & BR2 & & & & & & & \\
\hline ABC-CLIO & ABC-CLIO Reference Books & BR2 & & & & & & & \\
\hline ProQuest & EBL & BR1 & & & & & & & \\
\hline \multicolumn{10}{|c|}{$\begin{array}{l}\text { Notes: BR1 referes to Number of Successful Title Requests by Month and Title; BR2 refers to the Number of Successful Section Requests by Month and Title (refers to a } \\
\text { download or viewing of a particular section/chapter of an Ebook) }\end{array}$} \\
\hline
\end{tabular}

Figure 4. E-Book Report Spreadsheet. 


\section{EBSCO Discovery Services Reports}

Formation. The EBSCO Discovery Services (EDS) search box provides users with a quick and easy way to search the library's resources. Two reports help to determine how often and how well the EDS is used. First, the Interface Usage Report details the number of sessions, searches, full-text downloads, and abstract views conducted from EDS. Although monthly totals are provided, the annual usage is of most importance. The purpose here is to review searches and full-text downloads within EDS on an annual basis. The second report consists of a more indepth look at how searches are conducted within EDS. The EDS Search Term Report provides a look into the top search terms used in EDS.

Execution. The data for the interface usage report comes directly from EBSCO. After receiving university-specific statistics, the information is transferred to an Excel document for long-term recordkeeping. After data has been collected for a number of years, the report can be reviewed for long term trends (see Figure 5).

\begin{tabular}{|c|c|c|c|c|c|c|c|c|c|c|c|c|c|}
\hline \\
\hline \multicolumn{14}{|c|}{$\begin{array}{l}\text { Interface Usage Report } \\
\text { Site: TRINITY UNIV Detail Level: Interface Period: January } 2015 \text { - December } 2015\end{array}$} \\
\hline & & & & & & & \multicolumn{7}{|c|}{ Site: TRINITY UNIV Detail Level: Interface Period: January 2015 - December 2015} \\
\hline $\begin{array}{l}\text { InterfacelD/ } \\
\text { Version }\end{array}$ & Year & Month & Sessions & Searches & Total Full Text & $\begin{array}{l}\text { PDF Full } \\
\text { Text }\end{array}$ & $\begin{array}{l}\text { HTML Full } \\
\text { Text }\end{array}$ & Image/Video & Abstract & $\begin{array}{l}\text { Smart Link } \\
\text { To }\end{array}$ & Custom Link & $\begin{array}{l}\text { Total Full-Text + } \\
\text { Abstacts }\end{array}$ & $\begin{array}{l}\text { Search Clicks } \\
\text { (main) }\end{array}$ \\
\hline eds / live & 2016 & December & & & & & & & & & & & \\
\hline eds / live & 2016 & November & & & & & & & & & & & \\
\hline eds / live & 2016 & October & & & & & & & & & & & \\
\hline eds / live & 2016 & September & & & & & & & & & & & \\
\hline eds/live & 2016 & August & & & & & & & & & & & \\
\hline eds / live & 2016 & July & & & & & & & & & & & \\
\hline eds / live & 2016 & June & & & & & & & & & & & \\
\hline eds / live & 2016 & May & & & & & & & & & & & \\
\hline eds / live & 2016 & April & & & & & & & & & & & \\
\hline eds / live & 2016 & March & & & & & & & & & & & \\
\hline eds / live & 2016 & February & & & & & & & & & & & \\
\hline eds / live & 2016 & January & & & & & & & & & & & \\
\hline Totals & & & 0 & 0 & 0 & 0 & 0 & 0 & 0 & 0 & 0 & 0 & 0 \\
\hline
\end{tabular}

Figure 5. Interface Usage Report.

The search-term report is compiled in-house and the data is drawn from Google Analytics. Most discovery service providers can provide instructions on how to setup Google Analytics in relation to the discovery service. Google Analytics provides a variety of data 
points. Search terms are of most importance and should be evaluated with the group of librarians/liaisons at the end of each semester (fall and spring). The goal is to assess how users are searching from within the discovery layer (see Figure 6).

\begin{tabular}{|c|c|c|c|}
\hline \multicolumn{2}{|c|}{ Fall 2015: Top 20 Searches } & \multicolumn{2}{|c|}{ Spring 2016: Top 20 Searches } \\
\hline aeneid & 26 & $\begin{array}{l}\text { (Harvard AND Business } \\
\text { AND Review) }\end{array}$ & 98 \\
\hline $\begin{array}{l}\text { (food) AND (marketing) } \\
\text { AND (children) }\end{array}$ & 23 & $\begin{array}{l}\text { (Chronicle AND "of" } \\
\text { AND Higher AND }\end{array}$ & 89 \\
\hline $\begin{array}{l}\text { LoDolce, M. E., Harris, J. } \\
\text { L., }\end{array}$ & 21 & avoiding twisted pixels & 34 \\
\hline bacchae & 19 & Avoiding Twisted Pixels & 27 \\
\hline love & 18 & $\begin{array}{l}\text { (image AND } \\
\text { manipulation) }\end{array}$ & 17 \\
\hline ain't no makin it & 15 & eleanor of aquitaine & 17 \\
\hline bluebeard & 15 & fruit chan & 17 \\
\hline happiness & 15 & asdf & 16 \\
\hline
\end{tabular}

Figure 6. Search Term Report.

\section{Trials}

Formation. Trials provide a temporary, no-cost opportunity to explore electronic resources before making the decision to subscribe or purchase. This is a major part of any eresources job and one that needs strong organization and strategy to implement well. Arranging trial access to a particular electronic resource is extremely valuable to the selection process, and because e-resources represent a significant portion of the library's material budget, trials of new databases provide an opportunity for the campus to examine their suitability.

Librarian liaisons spend considerable time reviewing resources on trial for ease of use, content appropriateness, subject relativity, and for the potential academic value the database will add to the university. It is essential to consider the best timing of those trials. For example, think about when students and faculty are most likely to have time to try out a new resource or at what 
point in the class would these new databases be worth trying out. At Trinity, trials are conducted twice a year (October and March) and are setup using Sierra's ERM as well as Google Docs to assist in organization of timeframes, prices, and final decisions. However, staying flexible is also necessary, as trial requests can come at any time. If there is interest from any student, faculty, or staff member, it might be necessary to research and reach out to the vendor for initial information on pricing, terms of use, and trial availability.

Execution. When an initial request for trial is received, first ensure that there is a need for the resource. For example, ask the requestor to associate the database with a subject area and offer information about the ways a database can be used in the current or future curriculum. Also conduct a brief review of the existing collection to see if that particular content is really needed or if it would replicate another resource. If the resource is unique or if it is something that is needed, move forward with a trial and document the trial start and end dates as well as any special notes and pricing information within the ERM and also on a Google Spreadsheet that the librarians can view.

There are several steps to remember throughout the trial period. The best way for remembering each step is to create a procedure/checklist that can be used time and time again on every resource. The checklist should detail the step-by-step process for making the record public and housing all of the necessary information within the trial resource record. Once a trial is active, be sure to email liaisons and/or requestor to let them know that the trial is available (see Figure 7). 


\section{Procedure - Database Trials}

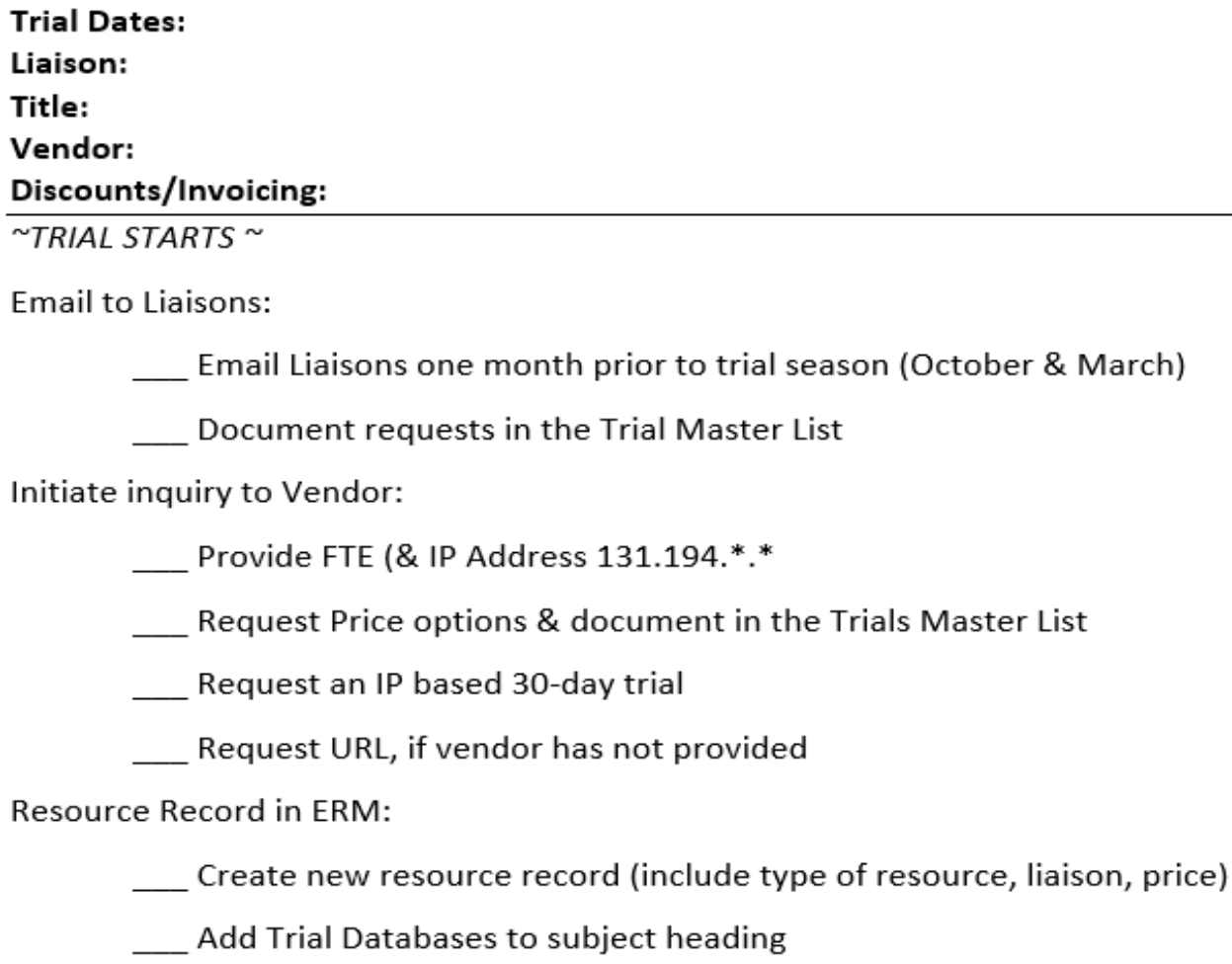

Figure 7. Sample Trial Checklist.

A major factor in the trials process is the need for regular communication with vendors in which discounts and licensing terms are discussed and often negotiated. Establishing good working relationships with vendors often means meeting with them a few times throughout the year. Additionally, vendors usually call the office throughout the year to checkup on their product and initiate discussions about potential interest in new products. Be sure to document any key information collected from vendors in the Google Spreadsheet.

Finally, create a Google Form (feedback document) to gather feedback, at the end of the trial period, on each resource. The survey should be short and get to the basic question of whether or not the library should purchase or subscribe to the resource. Justification for this decision is always helpful. Other optional survey questions may focus on interface, content, subject applicability, usability, and ease of navigation, as well as more simplistic items such as 
how easy is it to print, download, and email items directly from the platform. This type of feedback should be used to make a final decision to either purchase or subscribe. At the end of the trial month, and after having gathered and compiled the feedback, communicate with the other librarians which resources garnered interest. The librarians can use this information as they discuss which resources the library can seriously pursue based on that fiscal year's budget.

\section{Use of Resources Report}

Formation. The final play in the playbook consists of bringing all of the most important data into one visually appealing and informative report. The Use of Resources report contains usage data and assessment on e-books, databases, streaming media, discovery searches, circulation, and services. The report relies on data presented in Excel along with visual representations using Klipfolio dashboard software.

Execution. The Excel spreadsheet should be simple, straightforward, and contain any and all data to be represented in the Klipfolio dashboard. The spreadsheet should also include a separate tab titled "notes" to document any changes or unusual circumstances that might occur during a particular month or year. For example, major changes such as "construction blocking the entrance to our library during summer 2013 " should be well-documented in the notes tab as this could create drastic changes in the data. Once all of the data is placed in the spreadsheet, the data needs to be imported into the Klipfolio dashboard site. There are many dashboard platforms out there but most are costly and require a lot of set-up time. Klipfolio is easy to learn and easy to use. It allows users to import data from various places and then quickly and easily begin to create visual "Klips" from templates. It also provides for real-time data, once data is updated in an Excel sheet it is also updated in the dashboard. Plan on updating the Excel sheet monthly and 
importing the data into Klipfolio annually. It will also be best to review this data on an annual basis (see Figure 8).

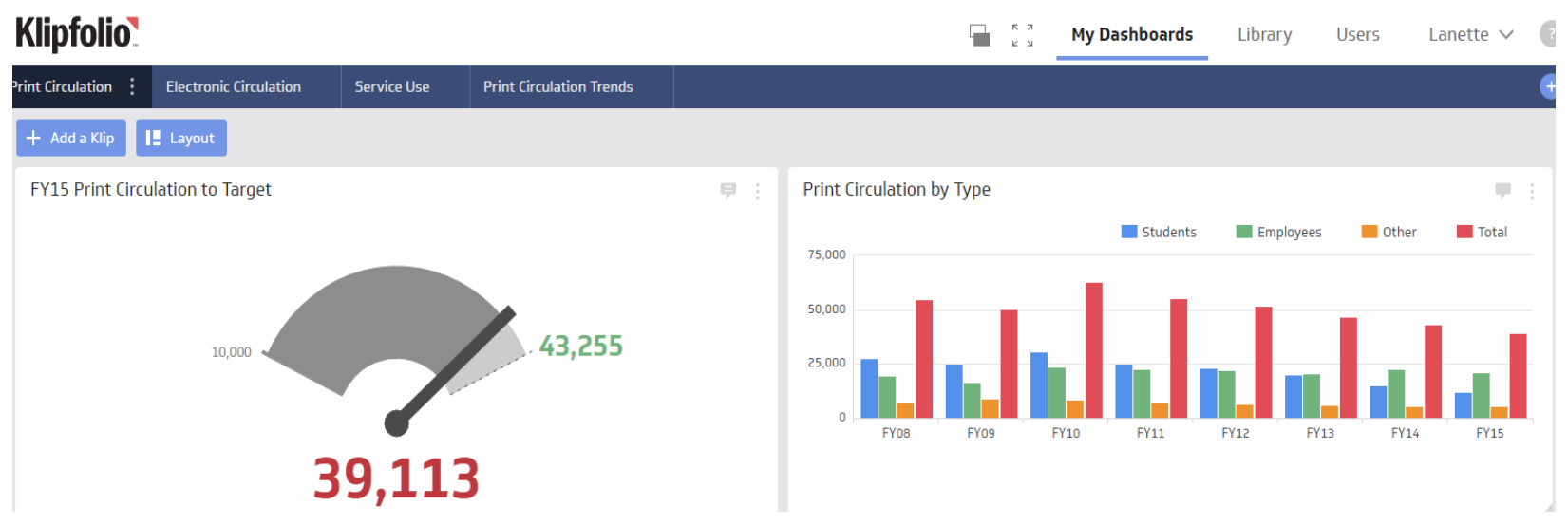

Figure 8. Klipfolio Dashboard for Use of Resources Report.

Conclusion

Every library, and probably every librarian, has strategies and "playbooks" for dealing with complex, extensive projects such as e-resources assessment. These guides are likely different from one institution to the next based on various factors. At Trinity University's Coates Library, for example, our assessment playbook helps us to meet deadlines and evaluate methods and routines for maximum productivity and value.

Clearly, diligent and rigorous assessment of e-resources offerings will continue to be a necessary factor as we track and analyze the value of our electronic collections. A playbook focused on e-resources assessment provides librarians with an intentional method for collecting, organizing, presenting, and using e-resources assessment data. Such a playbook should make the job of assessment more efficient and successful and allows more time for understanding the data rather than spending our time collecting it. Ultimately, it will result in better decision making. 


\section{References}

Carroll, J. D., Major, C., O'Neal, N., \& Tofanelli, J. (2012). Assessing ongoing electronic resource purchases: linking tools to synchronize staff workflows. Journal of Electronic Resource Librarianship, 2(7), 79-90.

COUNTER Codes of Practice. (2016, March). Retrieved from COUNTER: http://www.projectcounter.org/code_practice.html

Covey, D. T. (2002). Usage and Usability Assessment: Library Practices and Concerns. Council on Library and Information Resources, 1-92.

Emery, J., \& Stone, G. (2014). Developing workflow from TERMS: Techniques for electronic resource management. Library Faculty Publications and Presentations.

Fons, T., \& Jewell, T. (2007). Envisioning the future of ERM Systems. Serials Librarian, 52(1), $151-166$.

Fry, A. (2013). A hybrid model for managing standard usage data: principles for e-resources statistics workflows. University Libraries Faculty Publications, 1-19.

Nagra, K. A. (2009). The evaluation of use of electronic resources and services in academic libraries: A study of e-metrics and related methods for measurement and assessment. Journal of the Library Administration \& Management, 6(1), 28-41.

Peters, T. (2002). What's the use?: The value of e-resource usage statistics. New Library World, $39-47$.

Petrowski, M. J. (2015, February 27). ACRL Insider. Retrieved from new ACRL publication: 2013 Academic Library Trends and Statistics. http://www.acrl.ala.org/acrlinsider/archives/9956 
Shepherd, P. (2006). COUNTER: Usage statistics for performance measurement. Performance Measurement and Metrics, p. 142-152. 